\title{
Neoplastic Large Cell
}

National Cancer Institute

\section{Source}

National Cancer Institute. Neoplastic Large Cell. NCI Thesaurus. Code C37162.

A neoplastic cell with abundant amount of cytoplasm and/or large nucleus. 